Jpn. J. Hosp. Pharm.

$\left[\begin{array}{lll}\text { 17(6) } & 435-439 & (1991)\end{array}\right]$

各種消毒郕漫潤タオルマットおよび吸着マット

による病院内下足類の除菌効果

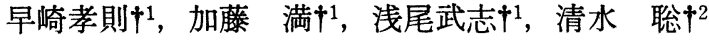 \\ 愛知医科大学附属病院薬剤部 ${ }^{1}$ \\ 丸石製薬株式会社中央研究所 ${ }^{2}$
}

\title{
The Sterilizing Effects of Bacteria for Wiping Hospital Footwear by Towel Mats Soaked with Various Antiseptics and Absorbent Mat
}

\author{
TAKANORI HAYAZAKI ${ }^{1}$, MITSURU KATO ${ }^{1}$, \\ TAKESHI AsaO ${ }^{1}$, SATOSI SHIMIZU ${ }^{2}$ \\ Department of Pharmacy, Aichi Medical University Hospital $\dagger^{1}$ \\ Research Center, Maruisi Pharmaceutical Co. Ltd. $\dagger^{2}$
}

(Received July 10, 1991)

\begin{abstract}
We investigated the effectiveness of towels used for removing bacteria which had adhered to the sole of hospital footwear after walking a set number of steps. In addition to an absorbent mat, towels for wiping were saturated with chlorhexidine gluconate, benzalkonium chloride, sodium hypochlorite or sterile distilled water. Towels soaked with the three types of antiseptic solutions exhibited a uniform sterilizing effect of bacteria with almost no relation to the number of times of wiping. When a towel soaked with sterile distilled water was used, the sterilizing effect diminished with successive wipes. Compared with the five methods, the absorbent mat had the weakest average sterilizing effect.
\end{abstract}

Keywords — wiping towel mat; absorbent mat; commercial antiseptics; sterile distilled water; Sterilizing effect of bacteria

は じめに

病院内の衛生管理区域を常に清潔に保つことは 感染防止対策を考えるにあたって極めて重要なこ とである ${ }^{1 \sim 3)}$. 当院薬剤部では調剂室の薬剤 部 員 出入口に1980年から $0.2 \%$ グルュン酸クロルヘキ

$\dagger^{1}$ 愛知県愛知郡長久手町岩作字雁又 $21 ; 21$, Karimata, Iwasaku, Nagakute-cho, Aichi-gun, 480-11 Japan

$\dagger^{2}$ 大阪市鶴見区今津中2-2-18; 2-2-18, Imazu-naka, Turumi-ku, Osaka, 538 Japan
シジン液を含ませた足拭きタオルマットを置き， 外部からの入室によって下足が持ち込んだ細菌類 の抑制を図ってきたが，薬液の乾燥が早く，2 時 間ごとに補充が必要なため，1990年以降は市販の 足拭き吸着マットに変更し, 現在に至っている. しかし足拭きタオルマットおよび吸着マットの除 菌効果を比較検討した報告はない。

そこで今回われわれは院内廊下をスリッパを履 いて一定距離歩行した後, 3 種類の消毒剂（グル コン酸クロルヘキシジン液, 次亜塩素酸ナトリウ ム液, 塩化ベンザルコニウム液）および隇菌水を 
含ませた足拭きタオルマットならびに吸着マット によるスリッパの除菌効果を調査した。

\section{試 験 方 法}

試験に用いるスリッパは裏の平面なものとし， エチレンオキサイドガス（以下，EO）で滅菌し た。また除菌に使用する足拭きタオルマットは $\mathrm{EO}$ 隇菌したタオルマット $(700 \times 400 \mathrm{~mm}$, 厚さ $20 \mathrm{~mm}$ ）に $0.2 \%$ グルコン酸クロルヘキシジン液 (以下, $\mathrm{CHX}), 0.01 \%$ 次亜塩素酸ナトリウム液 (以下， CL)，0.1\%塩化ベンザルコニウム液（以 下， BAC）拈よび減菌蒸留水（以下，AQA）各 $1 \ell$ を均一に含ませて作製した。

各実験者は EO 滅菌スリッパを履いてオールフ レッシュ空気強制換気( 6 回／時間)下の院内 3 階

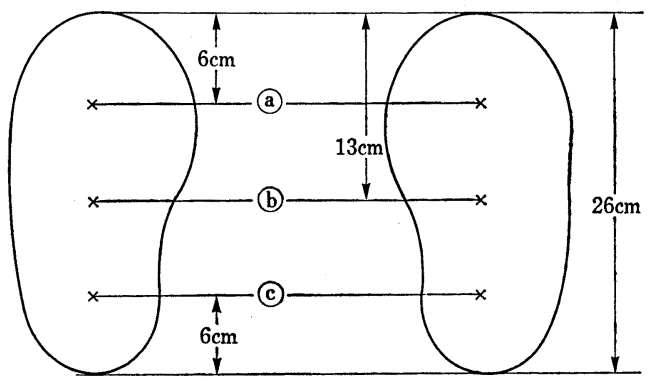

図 1. スリッパの菌採取位置
の指定廊下をそれぞれ 200 歩歩行した後，両足ス リッパ裏を 4 種類の足拭きタオルマットおよび吸 着マット（GM-30：ホギィディカル社; 以下, MAT $)^{4,5)}$ の一定籄所で 4 回ずつ足踏みして清拭 した。な打付着菌は 200 歩歩行後の清拭前および 同様の歩行と清拭操作を20分間隔で10回繰り返し た 1 回目（以下，(1)）５回目（以下，(2)，10回 目（以下，(3)）に図1に示した両足スリッパ裏の 各指定 3 力所〔つま先（以下，(a)，土踏まず（以 下, (b)), かかと (以下, (C))]の 6 カ所からスタ ンプアガー法6,7) で採取した。

各マットは使用中を除き，落下菌による污染を 防ぐために無菌ビニール布で覆った．採取菌の培 地には $\mathrm{CHX}, \mathrm{CL}, \mathrm{BAC}$ の 3 種類の消毒剂を中 和させるため，10倍濃度の中和混合液（レシチン : ツイーン 80 : ルブロール $\mathrm{W}:$ チオ硫酸ナトリウ ム $=5: 10: 10: 10$ ) 含有の内径 $3.6 \mathrm{~cm}$, 断面積 $10 \mathrm{~cm}^{2}$ のスタンプメディア BHI 培地 (栄研社) を用い, $37^{\circ} \mathrm{C}$ で 24 時間培養後にコロニー数をカ ウントし，主なコロニーは形態別に分離培養して 菌の同定を行った。

これら一連の実験は1990年 9 月，性別および体 重の違う A, B , C , D , E の 5 名の薬刘部員の 協力によって実施した。

表 1. 実験者のスリッパ清拭による各採取位置での細菌コロニー数

\begin{tabular}{|c|c|c|c|c|c|c|c|c|}
\hline \multirow{2}{*}{ 実検者 } & \multirow{2}{*}{ 性別 } & \multirow{2}{*}{$\begin{array}{l}\text { 体重) } \\
\text { (Kg) }\end{array}$} & \multicolumn{3}{|c|}{ 左足スリッパ } & \multicolumn{3}{|c|}{ 右足スリッパ } \\
\hline & & & (a) & (b) & (C) & (a) & (b) & (C) \\
\hline A & 男 & 72 & $12.5 \pm 12.6$ & $12.7 \pm 11.6$ & $10.4 \pm 9.9$ & $9.8 \pm 11.1$ & $7.8 \pm 8.2$ & $10.4 \pm 11.3$ \\
\hline B & 男 & 65 & $9.3 \pm 15.2$ & $8.5 \pm 12.0$ & $11.0 \pm 12.2$ & $6.9 \pm 13.2$ & $6.1 \pm 10.1$ & $7.3 \pm 11.5$ \\
\hline C & 男 & 57 & $7.6 \pm 9.5$ & $8.8 \pm 12.0$ & $5.7 \pm 6.1$ & $4.4 \pm 4.7$ & $5.4 \pm 6.7$ & $9.1 \pm 14.0$ \\
\hline $\mathrm{D}$ & 女 & 42 & $3.7 \pm 4.7$ & $5.3 \pm 8.3$ & $6.5 \pm 8.5$ & $6.8 \pm 9.7$ & $4.6 \pm 5.5$ & $4.8 \pm 5.5$ \\
\hline $\mathrm{E}$ & 女 & 40 & $4.3 \pm 5.5$ & $6.8 \pm 7.6$ & $5.6 \pm 4.2$ & $5.4 \pm 6.5$ & $5.5 \pm 6.6$ & $9.1 \pm 8.5$ \\
\hline 平 & & & $7.5 \pm 10.6$ & $8.4 \pm 10.5$ & $7.8 \pm 8.7$ & $6.7 \pm 9.5$ & $5.9 \pm 7.5$ & $8.1 \pm 10.5$ \\
\hline
\end{tabular}

(a), (b), (c)図 1 のスタンプアガー法による菌採取位置

数值は $\mathrm{CHX}, \mathrm{CL}, \mathrm{BAC}, \mathrm{MAT}, \mathrm{AQA}$ 清拭後の左右スリッパ各 3 力所採取 1 回目後, 5 回目後,

10 回目後の細菌コロニ-数の和の平均值 $\mathrm{SD}$ 


\section{結果および考察}

$\mathrm{A}, \mathrm{B}, \mathrm{C}, \mathrm{D}, \mathrm{E}$ 各実験者の 5 種類のマット による清拭(1)，(2)，(3)の左右スリッパ 採取 位 置 (a)（b)，(c)の細菌コロニー数をカウントして左右 それぞれの和の平均値 \pm SD を求め, 表 1 に示し た。

5 実験者の左足スリッパの細菌コロニ一数の和 の平均は@が $7.5 \pm 10.6$ ，(b) $8.4 \pm 10.5$, (c)が $7.8 \pm 8.7$ であり, 右足スリッパの平均は@が 6.7

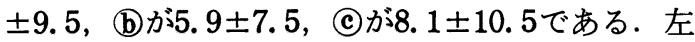

右スリッパ間に括ける数値に大きな差異は認めら れなかったことから, 左右 6 カ所のコロニー数の 和を基にして清拭方法, 清拭回数, 実験者間の総 合的な評価をするためにボンフェローニの検定を 行い, 表 2 の結果を得た．各清拭方法による(1), (2), (3)清拭後のスリッパから検出された細菌コロ 二一数の和の平均値から見た除菌効果は $\mathrm{BAC}>$ $\mathrm{CHX}>\mathrm{CL}>\mathrm{AQA}>\mathrm{MAT}$ の順であり, $\mathrm{AQA}$ に 対して CHX, BAC 拈よび CL は除菌効果にお いて $\mathrm{p}<0.01$ で有意の差が認められた.

AQA，CHX，CL，BAC，MAT の清拭前と

表 2. 各種清拭方法の清拭回数による細菌コロニー数

\begin{tabular}{|c|c|c|c|c|c|c|}
\hline \multirow{2}{*}{ 清拭方法 } & \multirow{2}{*}{$\begin{array}{l}\text { 奏 } \\
\text { 箬 }\end{array}$} & \multirow{2}{*}{ 清拭前 } & \multicolumn{2}{|c|}{ 清 } & \multicolumn{2}{|c|}{ 数 } \\
\hline & & & (1) & (2) & (3) & 平均 \# \\
\hline AQA & $\begin{array}{l}\mathrm{A} \\
\mathrm{B} \\
\mathrm{C} \\
\mathrm{D} \\
\mathrm{E}\end{array}$ & $\begin{array}{l}24.1 \\
29.5 \\
28.2 \\
32.0 \\
10.8\end{array}$ & $\begin{array}{l}4.5 \\
2.2 \\
4.0 \\
2.5 \\
8.0\end{array}$ & $\begin{array}{r}20.2 \\
5.8 \\
21.7 \\
6.5 \\
6.8\end{array}$ & $\begin{array}{l}21.8 \\
37.0 \\
22.5 \\
20.3 \\
10.0\end{array}$ & \multirow[t]{2}{*}{12.9} \\
\hline \multicolumn{2}{|l|}{ 平 均 } & 24.9 & 4.2 & 12.2 & 22.3 & \\
\hline $\mathrm{CHX}$ & $\begin{array}{l}\mathrm{A} \\
\mathrm{B} \\
\mathrm{C} \\
\mathrm{D} \\
\mathrm{E}\end{array}$ & $\begin{array}{l}13.5 \\
37.8 \\
22.7 \\
19.3 \\
11.2\end{array}$ & $\begin{array}{l}0.7 \\
0.8 \\
0 \\
0.5 \\
0.7\end{array}$ & $\begin{array}{r}14.0 \\
0.8 \\
0.5 \\
1.0 \\
4.7\end{array}$ & $\begin{array}{r}5.2 \\
11.3 \\
1.0 \\
1.3 \\
1.8\end{array}$ & \multirow[t]{2}{*}{$3.0 * *$} \\
\hline \multicolumn{2}{|l|}{ 平 均 } & 20.9 & 0.5 & 4.2 & 4.1 & \\
\hline C L & $\begin{array}{l}\mathrm{A} \\
\mathrm{B} \\
\mathrm{C} \\
\mathrm{D} \\
\mathrm{E}\end{array}$ & $\begin{array}{l}33.0 \\
27.0 \\
16.0 \\
27.8 \\
15.8\end{array}$ & $\begin{array}{l}7.0 \\
0.5 \\
8.8 \\
4.0\end{array}$ & $\begin{array}{r}11.3 \\
0.5 \\
2.2 \\
3.7 \\
2.2\end{array}$ & $\begin{array}{r}11.8 \\
2.0 \\
2.3 \\
9.7 \\
1.7\end{array}$ & \multirow[t]{2}{*}{$4.0 * *$} \\
\hline \multicolumn{2}{|l|}{ 平 均 } & 23.9 & 2.5 & 4.0 & 5.5 & \\
\hline $\mathrm{BAC}$ & $\begin{array}{l}\mathrm{A} \\
\mathrm{B} \\
\mathrm{C} \\
\mathrm{D} \\
\mathrm{E}\end{array}$ & $\begin{array}{l}22.3 \\
23.0 \\
23.2 \\
12.3 \\
18.7\end{array}$ & $\begin{array}{l}0.3 \\
0.7 \\
0.5 \\
0.3 \\
1.3\end{array}$ & $\begin{array}{l}2.0 \\
0.8 \\
3.5 \\
4.2 \\
3.7\end{array}$ & $\begin{array}{l}2.5 \\
3.3 \\
5.5 \\
1.5 \\
9.8\end{array}$ & \multirow[t]{2}{*}{$2.7 * *$} \\
\hline \multicolumn{2}{|l|}{ 平 均 } & 19.9 & 0.6 & 2.8 & 4.5 & \\
\hline MAT & $\begin{array}{l}\mathrm{A} \\
\mathrm{B} \\
\mathrm{C} \\
\mathrm{D} \\
\mathrm{E}\end{array}$ & $\begin{array}{l}33.8 \\
42.0 \\
19.2 \\
14.8 \\
15.5\end{array}$ & $\begin{array}{r}11.7 \\
23.8 \\
11.8 \\
2.7 \\
12.8\end{array}$ & $\begin{array}{l}18.5 \\
16.3 \\
12.8 \\
16.7 \\
13.3\end{array}$ & $\begin{array}{r}27.5 \\
16.7 \\
6.3 \\
7.5 \\
10.7\end{array}$ & \multirow[t]{2}{*}{13.9} \\
\hline \multicolumn{2}{|l|}{ 平均 } & 25.1 & 12.6 & 15.5 & 13.7 & \\
\hline
\end{tabular}

数值は各実験者の採取 6 力所の平均値

\#: 各実験者の清拭方法ごとの清拭回数 1 回目後 (1)), 5 回目後

(2)，10回目後 (3)）の細菌コロニー数の和の平均值

**: 清拭方法, 清拭回数, 実験者間でのボンフェロー二検定で AQA

に対して $\mathrm{p}<0.01$ で有意差あり 
(1)，(2)，(3)に打ける細菌コロニー数の変化を指標 とする各種タオルマットならびに MAT の清拭回 数による除菌効果は図 2 のとおりであり, 各種タ オルマットの細菌コロニー数は清拭回数が多くな るにつれて増加傾向を示し, 特に AQA の10回目 である(3)では清拭前と殆んど変わらぬ菌数が検出 されたが，CHX では(3)でも清拭前に対して $\mathrm{p}<$ $0.05, \mathrm{CL}$ と $\mathrm{BAC}$ では $\mathrm{p}<0.01$ で除菌効果に 有意差が認められた。しかしMAT では除菌力は 弱く，清拭前と比較して(1)，(2)，(3)のいずれの場 合も有意差は認められなかった。 3 種類の消毒剤 使用の足拭きタオルマットは AQA， MAT と異 なって付着菌を強く殺菌するため, 除菌効果が高 いと考える.

一方, 各種タオルマット拈よびMAT の清拭回 数による細菌コロニー数の変化をまとめると図 3 のように 1 回目清拭後である(1)では AQA に対し て $\mathrm{CHX}$ と $\mathrm{BAC}$ の除菌効果は $\mathrm{p}<0.05$ で有意 に高く, MAT は低くて $\mathrm{p}<0.01$ で有意差が認
められ，CL には大きな差はなかった５回目清 拭後である(2)では AQA に対して $\mathrm{CHX}, \mathrm{CL}$, $\mathrm{BAC}$ の除菌効果は高く, 特に $\mathrm{BAC}$ は $\mathrm{p}<0.01$ で有意差が認められたが，MAT では低く，また 10 回目清拭後の(3)では AQA に対して CHX, $\mathrm{CL}, \mathrm{BAC}$ の除菌効果は $\mathrm{p}<0.05$ で有意に高 $<$, MAT の除菌効果も有意差はないものの $\mathrm{AQA} \mathrm{よ}$ り優れた値を示した.

なお，清拭前と(1)，(3)清拭操作後のスリッパ裏 から検出された主な細菌はBacillus sp., Staphylococcus sp., Micrococcus sp., Corynebacterium sp., Acinetobacter sp., Pseudomonas sp. であ り, 真菌は Aureobacidiu sp., Cladosporium sp. であった。

\section{結語}

3 種類の消毒剂を含ませた足拭きタオルマット および吸着マット(MAT) を使用してスリッパ付 着菌をスタンプアガー法で採取し, 除菌効果につ

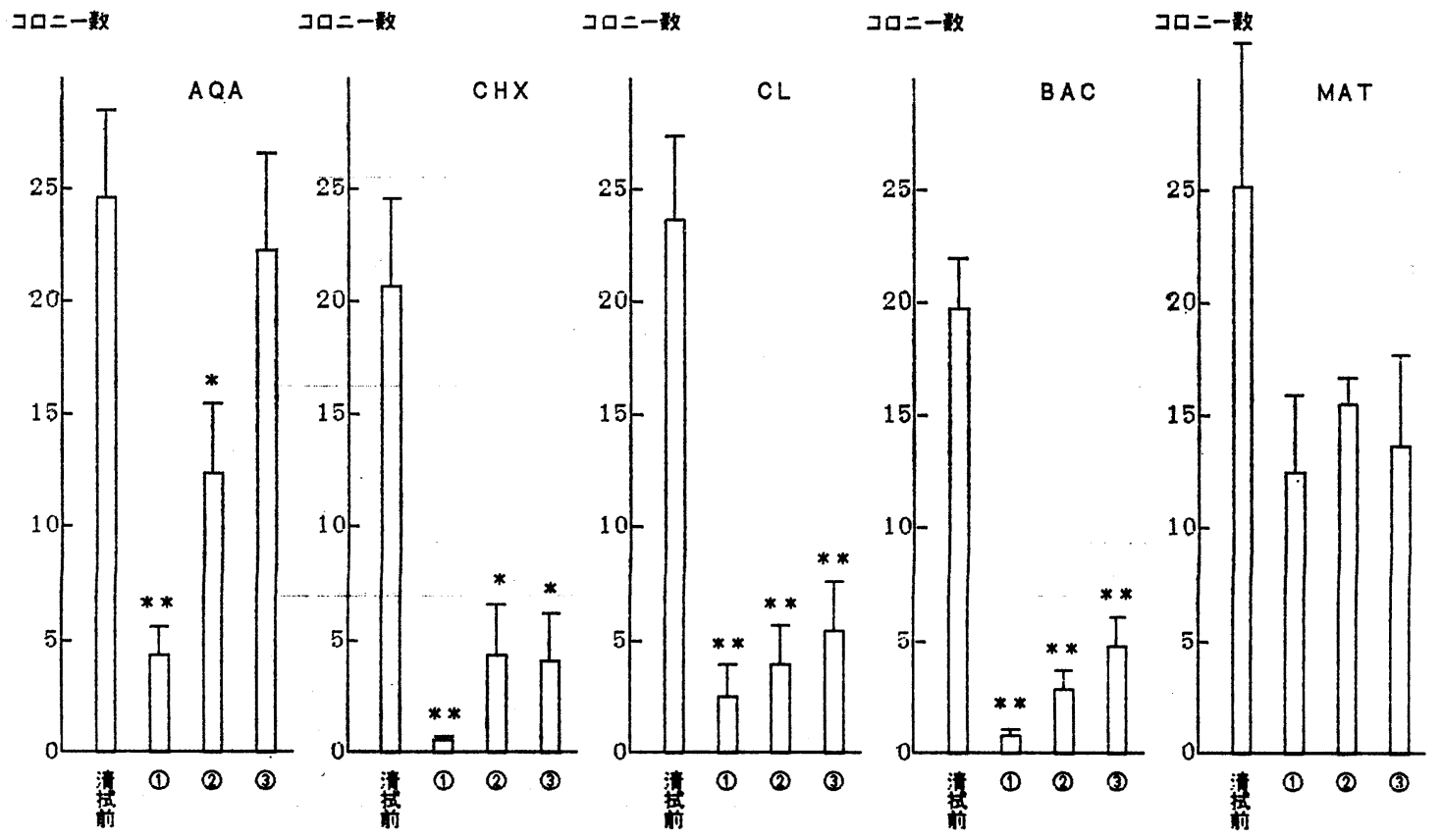

図 2. 清拭回数による細菌コロニー数の変化

(1): 清拭回数 1 回目後, (2): 同 5 回目後, (3): 同10回目後

* : 清拭前のコロニー数に対して $\mathrm{p}<0.05$ で有意差あり

** : 清拭前のコロニー数に対して $\mathrm{p}<0.01$ で有意差あり 

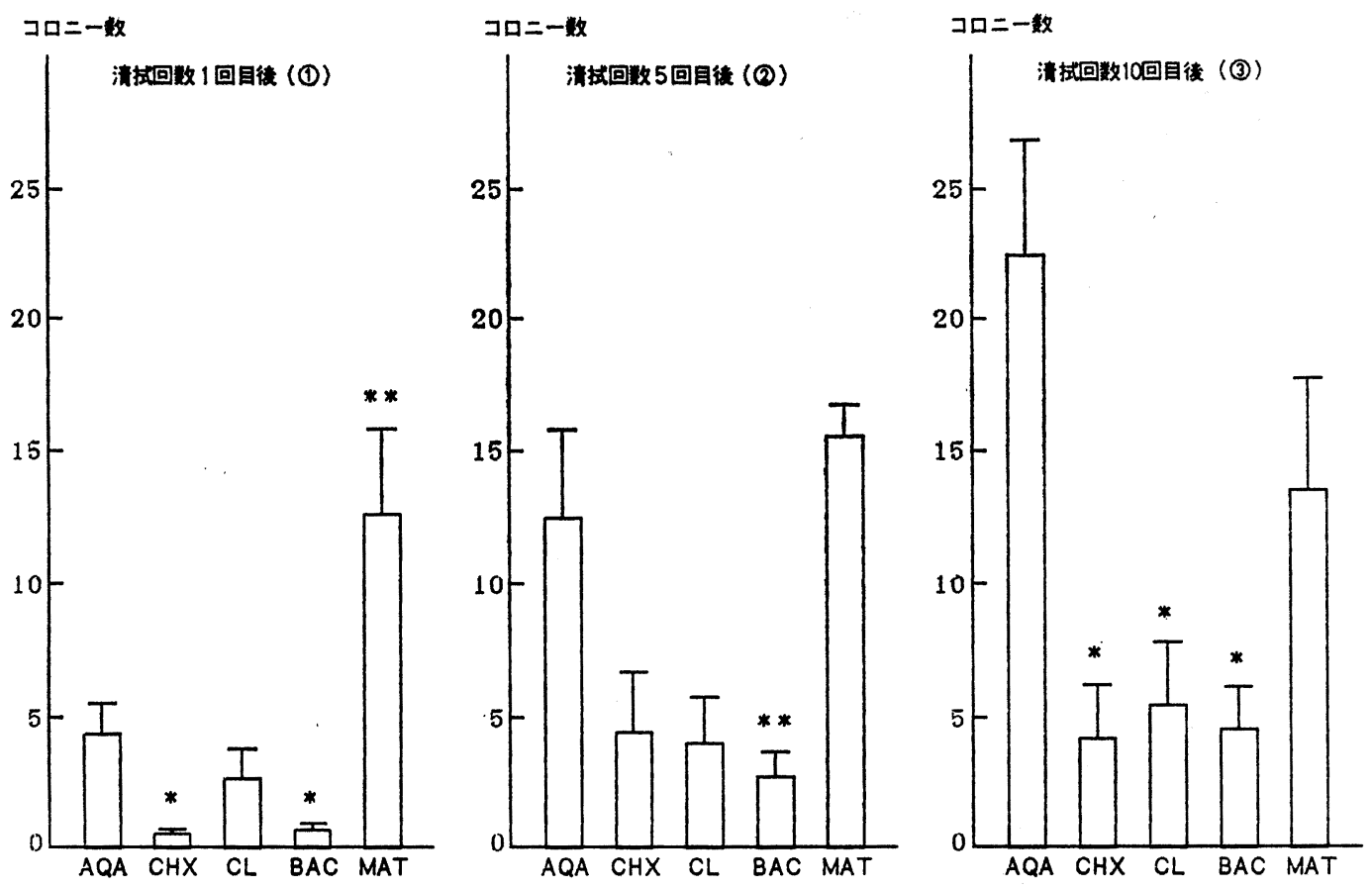

図 3. 各種タオルマットおよび MAT の清拭回数の推移による細菌コロニー数の变化 *:AQA に対して $\mathrm{p}<0.05$ で有意差あり ** : $\mathrm{p}<0.01$ で有意差あり

いて検討した結果，タオルマットではグルコン酸 クロルヘキシジン液 (CHX) と塩化ベンザルコニ ウム液 (BAC)を含ませたものの除菌効果が高く, 隇菌蒸留水では清拭回数の増加に伴って効果が期 待できなくなった．また MATの除菌効果は最も 弱いが, 10回までの清拭では回数に関係なく，ほ ぼ一定した効果が認められた。これらのことか ら, 消毒剂を含む足拭きタオルマットの衛生管理 上の有用性が確認された。

\section{引用文献}

1) 古橋正吉, 笹本恵美, 上田伊佐雄, 江波戸房司,
月刊薬事, 29, 2265-2272 (1987).

2) 青木紀道, 及川真紀子, 医器学, 57, 95-101 (1987).

3) 恵口利一郎, 医薬ジャーナル, 26,731-737(1990).

4）泉キョコ, 金川克子, 天津栄子, 本多政寧, 熊走 百合子, 手術部医学, 6, 308-313 (1985).

5）青木紀道, 及川真紀子, 手術部医学, 8, 422-426 (1987).

6）高木美保子, 野田美佐代, 谷口昌子, 水野サヨ子, 宮島節雄, 井上正晴, 野口 宏, 西川貞子, ICU と CCU, 8, 565-569 (1984).

7）小桐みどり, 斎藤直志, 荒川仁美, 清水ゆう子, 吉田暁美, 今野志緒, 鉒田 功, 高田知季, 手術 部医学, 11, 74-77 (1990). 